American Journal of Agricultural and Biological Sciences 5 (2): 143-147, 2010

ISSN 1557-4989

(C) 2010 Science Publications

\title{
Organic Alternative for Breaking Dormancy in Table Grapes Grown in Hot Regions
}

\author{
Consuelo Corrales-Maldonado, Miguel Angel Martinez-Tellez, Alfonso A. Gardea, \\ Antonio Orozco-Avitia and Irasema Vargas-Arispuro \\ Center for Research and Development in Food, AC Km 0.6, Road to Victory, \\ Hermosillo, Sonora, Mexico, CP 83000
}

\begin{abstract}
Problem statement: In warm-winter regions, the need for intervention of chemical means to break bud rest becomes a dominant factor for maintaining economic production of table grapes. However, the problem is more acute when farmers want to grow organic table grapes in the absence of environmentally-friendly budbreak promoters. Approach: This study aimed to evaluate the effect of a mix of naturally occurring Garlic Compounds (GC) in comparison to the conventional use of hydrogen cyanamide to promote budbreak and its effects on cluster quality in four table grape cultivars fieldgrown in hot region (Sonora Desert). Results: Four cultivars responded to GC, the vines bursting bud about 3 weeks after application. Quality of fruit from 4 cultivars treated with GC was excellent. Clusters weigh and berry sizes were larger than other treatments. Conclusion: Ability of GC to break dormancy in table grape grown in Sonora Desert has significant implications for organic table grape production in hot regions.
\end{abstract}

Key words: Garlic compounds, budbreak, hydrogen cyanamide, grape production

\section{INTRODUCTION}

Growing grapevines (Vitis vinifera L.) in warm regions still poses agronomic challenges. Interest in bud dormancy breaking agents is closely related to commercial attempts to grow grapevines in mild winter locations, where chilling requirements are not necessarily met and, in absence of chemical budbreaking agents, the results are uneven budbreak and low budbreak rates, which lead to management problems later in the growth season, resulting in reducing yield (Erez, 1987), uneven maturity and delayed harvests are problems as well. In the Sonoran Desert in NW Mexico the problem is acute and although low-chilling cultivars are used, continuous chemical applications to release buds from dormancy are required, as elsewhere (Shulman et al., 1983).

Many investigations have been conducted to artificially interrupt dormancy in grapevines with synthetic chemicals (Shulman et al., 1983; Weaver et al., 1961; Lin and Wang, 1985; Nir et al., 1988; Zelleke and Kliewer, 1989; Dookoozlian and Wiliams, 1995). Among such products, Hydrogen Cyanamide $\left(\mathrm{H}_{2} \mathrm{CN}_{2}\right)$ (Dormex, BASF) has been the most effective bud breaking agent for field use (Zelleke and Kliewer, 1989) It is very effective and leads to early and vigorous vegetative growth. Despite these attributes, hydrogen cyanamide is not accepted by organic protocols for grape production. The increasingly demand for organic produce, as well as premium prices (although premium prices do not necessarily translates into higher profits) for organically grown fruits, has motivated farmers be convert a sizeable amount of farmland from traditional agricultural practices to the production of organic foods. Thus, it is necessary to find environmentally friendly and operator safer budbreak promoters that are as effective as hydrogen cyanamide, suitable for organic table grape production.

Seeking for new alternatives to promote early budbreak, Kubota et al. (1999a) demonstrated that fresh garlic paste (Allium sativum L.) applied to cross sectional cut surface of Kyoho, Delaware, Neo Muscat grapevine canes, immediately after pruning was more efficient than calcium cyanamide. Similar satisfactory results were also obtained by using garlic-derived compounds in Perlette and Flame Seedless grapevines without exposure to chilling (Vargas et al., 2008). Both studies were done using cuttings, forced under controlled conditions. In this study we evaluated the effect of a mix of naturally occurring Garlic Compounds (GC) in comparison to the conventional use of hydrogen cyanamide to promote budbreak and its

Corresponding Author: Vargas-Arispuro Irasema, Center for Research and Development in Food, AC Km 0.6, Road to Victory, Hermosillo, Sonora, Mexico, CP 83000 Tel: (662)289-2400 Fax: (662)280-0381 
effects on cluster quality in four table grape cultivars field-grown in hot region (Sonora Desert). Also, we measured changes in Flame Seedless buds metabolic heat production $(\mathrm{Rq})$ after treatments and during forcing conditions as an indicator of overall metabolic changes associated to such treatments.

\section{MATERIALS AND METHODS}

General procedure: Although this study started since 2004, for the purpose of this article we focused on the 2006-2007 season data. The trials were conducted in three commercial vineyards, located in Pesqueira, Mexico $\left(29^{\circ} 20^{\prime} \mathrm{N}, 110^{\circ} 51^{\prime} \mathrm{W}\right)$ at an elevation of 345 masl. The vineyard was planted with self-rooted Vitis vinifera cultivars Perlette, Flame Seedless, Superior Seedless and Red Globe. Plot size for each cultivar was 1.5 ha. The pruning was done on January 2, 6, 9 and 16 in Perlette, Flame S., Red Globe and Superior S., respectively. Treatments were applied one day after pruning. All sprays were done with backpack sprayers ensuring a thorough wetting of buds. Ripening was determined by measurements of Total Soluble Solids (TSS), harvest was done at a commercial maturity between 14 and $17^{\circ}$ Brix. All standard viticultural practices for production of export table grapes were followed.

Field experiment: Treatments were (a) GC 3\% (v/v) (garlic preparation, patent in process), (b) A standard $5 \%$ (v/v) hydrogen cyanamide $\left(\right.$ Dormex $^{\circledR}$ ) and (c) Untreated control. On each cultivar, each treatment was applied to an acreage estimated of half a hectare. Bud phenology was followed by monitoring budbreak in ten 2-bud spurs per vine in 10 plants per cultiva. Monitoring was done twice a week until $90 \%$ of the buds bursted. Budbreak was recorded when buds reached the greentip stage (Coombe, 1995). Budbreak percentage data were analyzed by ANOVA considering a two-way factorial arrangement of treatments for budbreak promoting treatments and time. Percentage data were transformed to arcsine for analysis and transformed back to percentage for graphics. Mean separation, when applicable, was done by Tukey $(\alpha=$ 0.05 ) with SAS program (SAS Institute Inc, 1996).

Cluster quality: Cluster quality measurements were done only at commercial harvest, directly in the field packing facilities. Clusters on marked vines were counted and five clusters per vine were randomly selected and weighed. A sample of three berries was selected from each cluster for assessment of berry diameter with a graduated hoop and Total Soluble Solids (TSS) with a PAL 1 temperature compensated refractometer (Atago, Tokyo, Japan). Cluster and berry quality measurements data were analyzed by Analysis Of Variance (ANOVA), using NCSS (2005), while mean comparisons were done by Tukey $(\alpha=0.05)$.

Calorimetric measurements: For a calorimetric follow up of bud metabolism after the same treatments mentioned before, six node cuttings from current season growth were sprayed and forced to break under controlled conditions of $25^{\circ} \mathrm{C}$ and a $16 / 8$ photoperiod, their basal ends were kept immersed in water and water was changed every other day. This experiment was done only on Flame Seedless. Metabolic heat production by buds was measured at 0,7 and 14 days after treatments. Six replications per date were done and sample size was adjusted to yield appropriate heat outputs. Metabolic heat was measured with a differential scanning calorimeter (CSC 4100; Calorimetry Science Corporation, Pleasant Grove, Utah) working in the isothermal mode at $25^{\circ} \mathrm{C}$ for $3000 \mathrm{sec}$. The instrument has a baseline sensitivity $\pm 1 \mu \mathrm{W}$ and a working range of $-30-110^{\circ} \mathrm{C}$. Temperature around the DSC chamber was maintained at $15^{\circ} \mathrm{C}$ with a refrigerated circulating bath (Polyscience, Niles, IL). A flux of dry nitrogen at $175 \mathrm{~g} \mathrm{~cm}^{-2}$ was used to prevent moisture condensation inside the instrument. Samples were measured in three $1 \mathrm{~cm}^{3}$ hastelloy ampoules with removable lids. Metabolic heat $\left(\mathrm{R}_{\mathrm{q}}\right)$ rate was expressed on a dry-weight basis (Gardea et al., 2000). $R_{q}$ means were calculated on six replicates on each sampling date. Data were analyzed by ANOVA and means separation was done according to Tukey ( $\alpha$ $=0.05)$ (SAS Institute Inc, 1996).

\section{RESULTS AND DISCUSSION}

Effect on budburst rate of table grape cultivars: The effect of natural budbreaking agent GC was measured, quantifying the percentage of bud-burst after applying GC on buds from 4 cultivars and was compared with hydrogen cyanamide and untreated control. Both GC and hydrogen cyanamide promoted an early budbreak in the 4 cultivars, hastened budbreak by 19-28 days compared to the control (Fig. 1). Data analysis of budbreak shown no significant interaction between GC and hydrogen cyanamide to Perlett, Flame S. and Superior S. Cvs., but did found among the two treatments and the control. For Red Globe $\mathrm{Cv}$ significant interaction was found.

The budbreak of Cv. Flame Seedless (Fig. 1FS) was initiated 22 days from application GC $3 \%(\mathrm{v} / \mathrm{v})$ and hydrogen cyanamide 5\% (v/v). Untreated plants were initiated the budbreak 28 days after that the plants treated. 


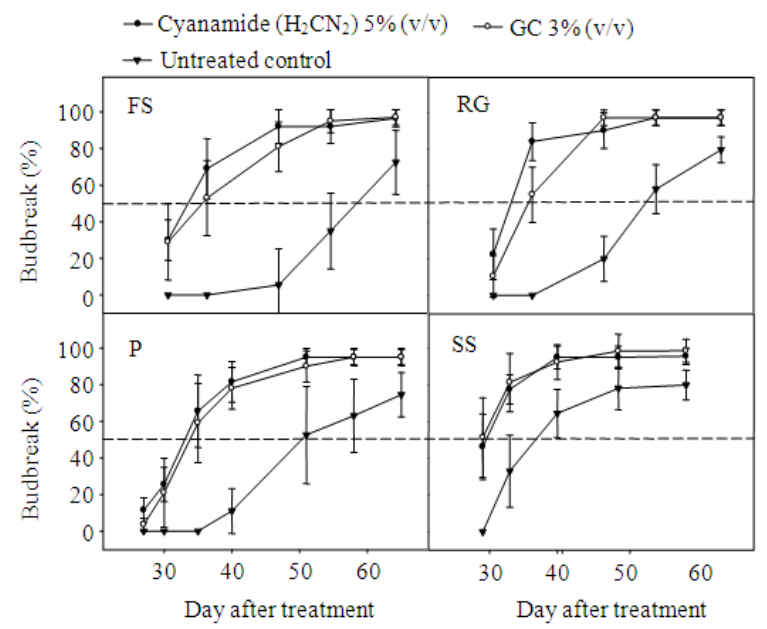

Fig. 1: Budbreak kinetics of four table grape varieties (FS: Flame Seedless, RG: Red Globe, P: Perlette and SS: Superior Seedless) treated with hydrogen. Bars represent standard deviations $(\mathrm{n}=10)$

In this cultivar hydrogen cyanamide and $\mathrm{GC}$ reached over 50\% budbreak, 36 Days After Treatment (DAT) and control reached 50\% budbreak at 58 DAT. The budbreak of Cv. Red Globe (Fig. 1RG) was initiated 25 days from application GC $3 \%(\mathrm{v} / \mathrm{v})$ and hydrogen cyanamide $5 \%(\mathrm{v} / \mathrm{v})$. Untreated vines were initiated the budbreak 27 days after that the vines treated. The 50\% of budbreak was reached in Red Globe at 32 DAT using hydrogen cyanamide and 34 DAT using GC. Untreated vines reached 50\% budbreak at 43 DAT. Vines of $\mathrm{Cv}$. Perlette Seedless (Fig. 1 PS) were initiated the budbreak 26 days from application GC 3\% (v/v) and 23 days from application hydrogen cyanamide $5 \%(\mathrm{v} / \mathrm{v})$. Untreated vines were initiated the budbreak 15 days after that the vines treated. Plants treated with hydrogen cyanamide and GC reached 50\% of budbreak at 33 DAT. Untreated vines reached the $50 \%$ of budbreak at 50 DAT. Vines of Cv. Superior Seedless (Fig. 1 SS) initiated the budbreak 20 days from application GC 3\% $(\mathrm{v} / \mathrm{v})$ and hydrogen cyanamide 5\% (v/v), this meant 11 days in advance that untreated vines. The $50 \%$ of budbreak was reached in Superior at 28-29 DAT using GC and hydrogen cyanamide. Untreated vines reached $50 \%$ budbreak at 39 DAT. Our data show that application of GC in each vine cultivars was able to promote an early budbreak, similar to hydrogen cyanamide. The vineyard treated have reached budburst at expecting date, it is defined by Coombe (1995) when the $50 \%$ buds on fruiting canes have reached the greentip bud stage. The untreated vines had a marked delay in budbreak. This result coincides with that reported by Botelho and Pavanello (2007) with the use of Bioalho in cultivar Cabernet Sauvignon. Kubota et al. (1999b) concluded that the effect to promote budbreak of garlic preparations is due to sulfur-containing compounds like diallyl mono, di and tri-sulfides and dimethyl disulfide. Also, Hartmann et al. (2000) attributed the effect of interrupting the dormancy of different species of deciduous plants to substances with sulfur molecules. Different sulfur compounds are components of GC, which were previously reported (Vargas et al., 2008). The mechanism by which sulfur compounds can induce bud breaking continues to be unknown. However, progress has been made in elucidating the implied routes in the regulation of sulfur in relation to the vegetative growth of plants (Hawkesford and de Kok, 2006). In this process sulfur is fixed as cysteine by the plants after a process of reduction (Saito, 2000). Cysteine is the initial material for the production of reduced glutathione, which is responsible for detoxify cells through the elimination of free radicals and reactive species that accumulate during different types of stress (Saito, 2004; Zang, 2004). According to Tohbe et al., (1998), exogenous applications of reduced glutathione induced bud breaking on buds of grapevines of $\mathrm{Cv}$. Delaware. If the sulfur molecules derived from garlic can be assimilated by the plant in the latent stage, might be the increased of this tripeptide in the ecodormant stage as stimuli that lead the dormancy release in vines but this remains to be elucidated.

Effect of GC on fruit quality: Berry quality characteristics are an important factor for consumer acceptance, why it was assessed the effect of GC on cluster development and determine its influence on clusters and berries characteristics such as size, weight and maturity. Table 1 shows the comparison between clusters produced under GC treatment, hydrogen cyanamide and untreated control. Quality measures were done at harvest time. Treatment using GC resulted in highest number of cluster, cluster weight and berry diameter in the 4 cultivars evaluated. Exceptional cluster weight of Red Globe was markedly larger. The SST ( ${ }^{\circ}$ Brix) resulted higher values with treatment of hydrogen cyanamide in all cultivars evaluated; however, there were no significant differences $(\alpha=0.05)$ to this parameter of quality between hydrogen cyanamide and GC. SST concentration is also an important factor of production, because, harvest date is determined by soluble solids concentration in range of $14-17.5 \%$ depending on cultivar and production area (Sonego et al., 2002). Untreated vines had very poor quality fruits, also cluster weight was less and small berry size. In addition, quality of fruit from 4 cultivars treated with GC was excellent. Untreated vines had variable quality fruit. 
Table 1: Effect of dormancy breaking agents on cluster and berry quality of four table grape cultivars under commercial management

\begin{tabular}{|c|c|c|c|c|}
\hline Treatment & $\begin{array}{l}\text { Cluster } \\
\text { number }\end{array}$ & $\begin{array}{l}\text { Cluster } \\
\text { weight }(\mathrm{g})\end{array}$ & $\begin{array}{l}\text { Total soluble } \\
\left.\text { solids ( }{ }^{\circ} \text { Brix }\right)\end{array}$ & $\begin{array}{l}\text { Berry } \\
\text { diameter }(\mathrm{mm})\end{array}$ \\
\hline \multicolumn{5}{|c|}{ Flame seedless } \\
\hline GC (3\%) & $48^{\mathrm{a}}$ & $415^{\mathrm{a}}$ & $16^{\mathrm{a}}$ & $21^{\mathrm{a}}$ \\
\hline $\mathrm{H}_{2} \mathrm{CN}_{2}(5 \%)$ & $42^{\mathrm{b}}$ & $349^{\mathrm{b}}$ & $17^{\mathrm{a}}$ & $21^{\mathrm{a}}$ \\
\hline Control & $32^{\mathrm{c}}$ & $242^{c}$ & $15^{\mathrm{a}}$ & $17^{\mathrm{b}}$ \\
\hline \multicolumn{5}{|l|}{ Red Globe } \\
\hline GC (3\%) & $17^{\mathrm{a}}$ & $1390^{\mathrm{a}}$ & $14^{\mathrm{a}}$ & $26^{\mathrm{a}}$ \\
\hline $\mathrm{H}_{2} \mathrm{CN}_{2}(5 \%)$ & $14^{\mathrm{a}}$ & $990^{\mathrm{b}}$ & $14^{\mathrm{a}}$ & $25^{\mathrm{a}}$ \\
\hline Control & $15^{\mathrm{a}}$ & $440^{\mathrm{c}}$ & $8^{\mathrm{b}}$ & $20^{\mathrm{b}}$ \\
\hline \multicolumn{5}{|c|}{ Superior seedless } \\
\hline $\mathrm{GC}(3 \%)$ & $25^{\mathrm{a}}$ & $585^{\mathrm{a}}$ & $15^{\mathrm{a}}$ & $21^{\mathrm{a}}$ \\
\hline $\mathrm{H}_{2} \mathrm{CN}_{2}(5 \%)$ & $25^{\mathrm{a}}$ & $585^{\mathrm{a}}$ & $16^{\mathrm{a}}$ & $19^{\mathrm{a}}$ \\
\hline Control & $20^{\mathrm{b}}$ & $389^{\mathrm{b}}$ & $15^{\mathrm{a}}$ & $19^{\mathrm{a}}$ \\
\hline \multicolumn{5}{|l|}{ Perlette } \\
\hline GC (3\%) & $32^{\mathrm{a}}$ & $485^{\mathrm{a}}$ & $16^{\mathrm{a}}$ & $21^{\mathrm{a}}$ \\
\hline $\mathrm{H}_{2} \mathrm{CN}_{2}(5 \%)$ & $26^{\mathrm{b}}$ & $435^{\mathrm{a}}$ & $16^{\mathrm{a}}$ & $20^{\mathrm{a}}$ \\
\hline Control & $24^{\mathrm{b}}$ & $424^{\mathrm{a}}$ & $13^{\mathrm{b}}$ & $17^{\mathrm{b}}$ \\
\hline
\end{tabular}

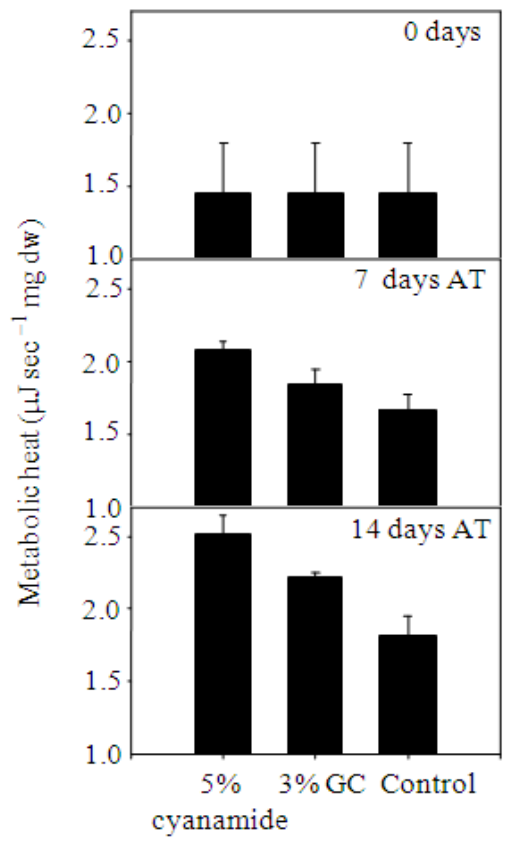

Forcing period(days)

Fig. 2: Metabolic heat production by flame seedless buds forced to break with hydrogen cyanamide $(5 \% \mathrm{v} / \mathrm{v}), \mathrm{GC}(3 \% \mathrm{v} / \mathrm{v})$ and untreated controls at 0,7 and 14 days after treatment. Forcing conditions of $25^{\circ} \mathrm{C}$ and a $16 / 8$ photoperiod. Bars represent standard deviations $(n=6)$

Calorimetric measurements result: Changes in Flame seedless buds metabolic activity was measured at 0,7 and 14 days after GC 3\% (v/v), hydrogen cyanamide $5 \%(\mathrm{v} / \mathrm{v})$ and distilled water application. Calorimetric assays were performed at forcing conditions using a growth chamber at $25^{\circ} \mathrm{C}$. Figure 2 shows bud calorimetry response. The isothermal calorimetry showed that the buds exposed to hydrogen cyanamide had the higher $\mathrm{R}_{\mathrm{q}}$ values $\left(2.5 \mu \mathrm{J} \mathrm{sec} \mathrm{mg}^{-1} \mathrm{dw}^{-1}\right)$ at 14 days after treatment apply, following by GC with $R_{q}$ value of $2.2 \mu \mathrm{J} \mathrm{sec}^{-1} \mathrm{mg}^{-1} \mathrm{dw}^{-1}$. The control showed the lowest $\mathrm{R}_{\mathrm{q}}$ value $\left(1.8 \mu \mathrm{J} \mathrm{sec}^{-1} \mathrm{mg}^{-1} \mathrm{dw}^{-1}\right)$. The $\mathrm{R}_{\mathrm{q}}$ values were statistically different $(\alpha=0.05)$ in the time, but not between treatments. These results are consistent with the results obtained in the budbreak percentage (Fig. 1), even though, the heat of metabolism of buds began well in advance of budbreak and long before any morphological change was visible. The results of metabolic heat in this study provide accurately information of actual timing of induction of dormancy release, thereby enabling the detection of early changes following this induction. In commercial vineyards where the time of harvest is very important, this could be an excellent tool (Gardea et al., 1994). In the case of Sonora, Mexico, the table grapes are exported to different countries and the harvest time must to be before those other table grapes producer countries arrive to this markets.

\section{CONCLUSION}

GC promoted budbreak in all cultivars of table grape evaluated in field-grown conditions in this study. This can result in table grape maturity being advanced by as mucho as weeks. The quality of fruit from 4 cultivars treated with GC was excellent. There is considerable potential for the application of GC in the organic production of table grapes in hot regions. The application of GC leads to a number of questions, including the correct dosage and timing application. The mechanism by which GC can induce grape bud break continues to be unknown and then further research should be directed to elucidate the mode of action of this budbreaking agent.

\section{ACKNOWLEDGEMENT}

We would like to thank the Fundacion Produce Sonora for support this research, as well as Table Grape Producer Association for labor and use of vineyards.

\section{REFERENCES}

Botelho, R. and A. Pavanello, 2007. Effects of chilling and garlic extract on bud dormancy release in Cabernet Sauvignon grape cuttings. Am. J. Enol. Viticult. 58: 402-404. http://www.ajevonline.org/cgi/content/abstract/58/ $3 / 402$ 
Coombe, B.J., 1995. Growth stages of the grapevine: Adoption of a system for identifying grapevines growth stages. Aust. J. Grape Wine R., 1: 100-110. DOI: 10.1111/j.1755-0238.1995.tb00086.x

Dookoozlian, N. and E. Wiliams, 1995. Chilling exposure and hydrogen cyanamide interact in breaking dormancy of grape buds. Hortic. Sci., 30: $1244-1247$.

http://hortsci.ashspublications.org/cgi/content/abstr act $/ 30 / 6 / 1244$

Erez, A., 1987. Chemical Control of budbreak. Hort. Sci., 22: 1240-1243. http://cat.inist.fr/?aModele $=$ afficheN\&cpsidt $=7678459$.

Gardea, A.A., Y.M. Moreno, A.N. Azarenko, P.B. Lombard and L.S. Daley et al., 1994. Changes in metabolic properties of grape buds during development. J. Am. Soc. Hortic. Sci., 119: 756-760. http://journal.ashspublications.org/cgi/content/abstr act/119/4/75.

Gardea, A.A., M.E. Carbajal, J.A. Orozco, V.M. Guerrero and J. Llamas, 2000. Effect of chilling on calorimetric responses of dormant vegetative apple buds. Thermochim. Acta, 349: 89-94. DOI: 10.1016/S0040-6031(99)00500-6

Hartmann, T., S. Mult, M. Suter, H. Rennenberg and C. Herschbach, 2000. Leaf age-dependent differences in sulphur assimilation and allocation in poplar (Populus tremula x P. alba) leaves. J. Exp. Bot., 51: 1077-1088. http://jxb.oxfordjournals.org/cgi/reprint/51/347/1077.

Hawkesford, M. and L. de Kok, 2006. Managing sulphur metabolism in plants. Plant Cell Environ., 29: $\quad 382-395$. DOI: $10.1111 / \mathrm{j} .1365-$ 3040.2005.01470.x

Kubota, N., Y. Yamane, K. Toriu, K. Kawasu and T. Higuchi et al., 1999a. Identification of active substances in garlic responsible for breaking bud dormancy in grapevines. J. Jap. Soc. Hortic. Sci., 68: 1111-1117.

Kubota, N., M. Miyamuki, Y. Yamane, A. Kobayashi and F. Mizutani, 1999b. Breaking bud dormancy in grapevines cuttings with garlic volatiles. J. Jap. Soc. Hortic. Sci., 68: 927-931.

Lin, C. and T.Y. Wang, 1985. Enhancement of bud sprouting in grape single bud cutting by cyanamide. Am. J. Enol. Viticult., 36: 15-17. http://www.ajevonline.org/cgi/content/abstract/36/1/15

NCSS., 2005. Number Cruncher Statistical System. Kaysville, Utha.

http://www.ncss.com/download_previous.html
Nir, G., I. Klein, S. Lavee, G. Spieler and U. Barak, 1988. Improving grapevine budbreak and yields by evaporative cooling. J. Am. Soc. Hortic. Sci., 113: 512-517.

Saito, K., 2000. Regulation of sulfate transport and synthesis of sulfur-containing amino acids. Curr. Opin. Plant Biol., 3: 188-195. DOI: 10.1016/S1369-5266(00)80064-3

Saito, K., 2004. Sulfur assimilatory metabolism. The long and smelling road. Plant Physiol. 136:2443-2450. http://www.plantphysiol.org/cgi/reprint/136/1/2443

SAS Institute Inc., 1996. Version 6.12. Cary NC 27513USA. http://www.sas.com/partners/directory/hp/64bit.pdf

Shulman, Y., G. Nir, L. Fanberstein and S. Lavee, 1983. The effect of cyanamide on the release from dormancy of grapevine buds. Sci. Hortic., 19: 97104. DOI: 10.1016/0304-4238(83)90049-3

Sonego, L. S. Lurie, Y. Zuthi, T. Kaplonov and R. BenArie et al., 2002. Factors affecting taste scores of early season seedless table grape Cv. Mystery and Prime. J. Agric. Food Chem., 50: 544-548. DOI: 10.1021/jf0107151

Tohbe, M., R. Mochioka, R. Horiouchi, S. Ogata and T. Shiozaki et al., 1998. Roles of ACC and glutathione during breaking of dormancy in grapevine buds by high temperature treatment. J. Japan. Soc. Hortic. Sci., 67: 897-901.

Vargas, I., C. Corrales and M. Martínez, 2008. Compounds derived from garlic as bud induction agent in organic farming of table grape. Chilean J. Agric. Res., 68: 94-101. DOI: 10.4067/S071858392008000100009

Weaver, R., S.B. McCumeand and B.G. Coombe, 1961. Effects of various chemicals and treatment on rest period of grape buds. J. Enol. Viticult., 2: 131-142. http://www.ajevonline.org/cgi/content/abstract/12/ $3 / 131$.

Zang, M., 2004. A novel family of transporters mediating the transport of glutathione derivates in plants. Plant Physiol., 134: 482-491. http://www.plantphysiol.org/cgi/reprint/134/1/482

Zelleke, A. and W. Kliewer, 1989. The effects of hydrogen cyanamide on enhancing the time and amount of budbreak in young grape vineyards. Am. J. Enol. Viticult. 40: 47-51. http://www.ajevonline.org/cgi/content/abstract/40/ $1 / 47$ 